\title{
Pharmacological Features of Bioactive Milk Components: An Overview
}

\author{
Dr. P. Sankar ${ }^{1 *}$ and Dr. K. Ramya ${ }^{2}$ \\ ${ }^{1}$ Department of Veterinary Pharmacology and Toxicology, Veterinary College and Research Institute, India \\ ${ }^{2}$ Department of Veterinary Microbiology, Veterinary College and Research Institute, India
}

Submission: August 21, 2017; Published: September 08, 2017

*Corresponding author: Dr. P. Sankar, Assistant professor, Department of Veterinary Pharmacology and Toxicology, Tamil Nadu Veterinary and Animal Sciences University, Veterinary College and Research Institute, Namakkal-637002, India, Tel: 91-7598343591;

Email: drpsankarster@gmail.com

\section{Opinion}

Milk proteins are of immense high nutritional significance for human beings and also possess diverse functional properties like immunological protection and antioxidant effect. In general, the major protein fractions in bovine milk include caseins, immune globulins, lacto-ferrin, proteose-peptide fractions and minor whey proteins such as transfer in and serum albumin. In recent years milk proteins have attracted growing scientific and commercial interest as a source of biologically active molecules. The native milk proteins exhibit a wide range of biological activities that influence the digestive function, metabolic responses to absorbed nutrients, growth and development of organs and disease resistance. Whey proteins, in particular, have been identified with numerous putative functions related to reduction in the risks of many chronic human diseases reflected by the metabolic syndrome. Several whey protein based commercial products are available in the global market. In last decade, an increasing number of peptides with specific bioactivities originated from milk proteins have been identified. These milk peptides are liberated from milk proteins by enzymatic breakdown by digestive enzymes or by the proteinase enzyme produced by lactobacilli during fermentation of milk.

The synthesis, amount and bioactivity of peptides in fermented dairy products are governed by several factors like type of starters, nature of product, duration of fermentation and storage conditions. It is noteworthy that in these products peptides with different bioactivities, e.g. antimicrobial, antihypertensive, anti-oxidative, immune modulator and antithrombotic peptides may be formed at the same time. However, the optimization of peptide formation needs strict regulation. The technological standardization for the release of specific bioactive peptides in dairy products and the potential health benefits of these peptides warrant further research.
Evidence from clinical studies is indicating that milk proteins and their individual components exert many other therapeutic benefits that can be extended to humans. These potential benefits include, for example reduction of the risks of cardiovascular disease, obesity and type II diabetes, which are of global public health concern. Based on successful clinical trials, a few commercial products containing bioactive milk peptides have already been introduced to the growing markets worldwide. It can be envisaged that in the near future more similar products will be launched on worldwide markets. They could be targeted to infants, elderly and immune compromised people as well as to maintain good health status and prevent diet related chronic diseases.

In view of the current global trend of increasing incidences of obesity and related diseases, type II diabetes, in particular, more experimental research should be focused on bioactive milk peptides which can regulate appetite and blood glucose level. Other prospective areas with bioactive milk proteins and peptides include impairment of cognitive functions, memory related diseases and mood control. In this context, anti-oxidative and opioid properties of many milk peptides may be worth further investigations. Also, potential to reduce oxidative stress in the body via oral administration of anti-oxidative peptides may be of considerable interest in view of the inflammatory events caused by radical oxygen species in the living cells.

However, major issue for future research in this area would be isolation, their stability in new product system, safety, bioavailability, effects of processing and storage and their antagonistic and synergistic effects. Hence, separation and identification of these peptides and their pharmacodynamic studies are utmost important to formulate several drugs and beneficial functional foods for human and animal diseases. 
Your next submission with Juniper Publishers will reach you the below assets

- Quality Editorial service

- Swift Peer Review

- Reprints availability

- E-prints ServiceManuscript Podcast for convenient understanding

- Global attainment for your research

- Manuscript accessibility in different formats

( Pdf, E-pub, Full Text, Audio)

- Unceasing customer service

Track the below URL for one-step submission https://juniperpublishers.com/online-submission.php 